\title{
BOEKBESPREKINGEN
}

L. E. Groosman en D. Overkleeft (red.)

\section{DATA BASE OF DATA BEEST?}

Kluwer, Deventer, 1973, 301 p. (paperback $f 24,50$ ) ISBN 90-267-041 7-8.

\section{door Prof. A. B. Frielink}

Ondanks de provocerende, en wat populair aandoende titel, is dit een opmerkelijk boek, dat verdient door vele serieus geînteresseerden te worden gelezen. Opmerkelijk omdat het een waarlijk multidisciplinaire behandeling van het fenomeen "gegevensbank" en de daarmede verbonden problematiek van de bescherming van de persoonlijke levenssfeer (officiële aanduiding van privacy-bescherming) bevat.

Elf auteurs behorende tot verschillende vakgebieden bespreken in dit boek het onderwerp, ieder vanuit zijn eigen ervarings- en kenniswereld. De daarbij optredende overlappingen en doublures zijn miniem (dit is een compliment voor de redacteuren) en voor zover zij voorkomen helpen zij de lezer meer in zijn begripsen kennisvorming dan dat $z i j$ zouden storen.

Het boek is wel duidelijk gedateerd. Dit blijkt uit het ontbreken van een fundamentele, de gehele problematiek omvattende beschouwing. Zo'n beschouwing zou vandaag de dag over een onderwerp dat nog zo sterk in ontwikkeling is, ook niet gegeven kunnen worden. Er kan dan ook nog niet worden gesproken van een interdisciplinaire behandeling.

De twee delen waarin het boek is verdeeld hebben een verschillend karakter. In deel 1 (hoofdstuk $1 \mathrm{t} / \mathrm{m} \mathrm{4}$ ) zijn - in beknopte en duidelijke vorm - technologische feiten weergegeven. Het is naar mijn oordeel te betreuren dat daarbij de niet ongebruikelijke antropomorfische terminologie (,de computer controleert", ,het systeem vraagt", ,het programma is bekend met het subschema", enz.) niet meer is vermeden. De oningewijde krijgt hierdoor gemakkelijk de indruk dat de beschreven technologische systemen een eigen persoonlijkheid hebben (quod non) en met intelligente biologische wezens $\min$ of meer gelijk kunnen worden gesteld (quod non).

In deel II worden beschouwingen en deels speculaties gegeven vanuit sociologisch, juridisch, bestuurlijk, controle- en organisatorisch standpunt. Deze beschouwingen en speculaties hebben duidelijk de functie de gedachtenontwikkeling omtrent nut en gevaren van ge- makkelijk toegankelijke geintegreerde gegevensverzamelingen te stimuleren, meer dan eeuwig geldende uitgangspunten te formuleren.

Een enkele kritische opmerking:

- Bij de weergave van de Zweedse situatie (blz. 149/150) wordt, m.i. ten onrechte, niet expliciet gemaakt dat de grondwettelijke openheid van overheidsgegevens in dat land al sinds een geruim aantal jaren inhoudt dat bijv. ook de individuele (belastbare) inkomens volstrekt openbaar zijn. Zo'n mededeling zou de situa-

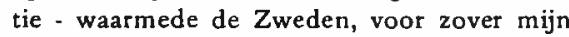
waarneming gaat, zeker niet ongelukkig zijn voor de Nederlandse lezer anzienlijk kunnen verhelderen. Hetzelfde geldt voor het feit dat een ieder in Zweden de inhoud van de bevolkingsregistratie (daar gehouden door de belastingdienst die in het boek merkwaardigerwijze wordt genoemd de National Tax Board) kan kopen, en daarbij een abonnement op de wijzigingen kan nemen;

- Op blz. 163/164 worden een aantal soorten gegevensverzamelingen inhoudende persoonsgegevens en gehouden door (semi-) overheids. en particuliere organisaties in Nederland, opgesomd. Het is verwarrend dat daarbij niet uitdrukkelijk wordt medegedeeld dat de gegevens over de ruim 750000 ziekenhuisopnamen, geregistreerd door de Stichting Medische Registratie, niet nominatief (en ook op geen enkele manier gekoppeld aan individuele patiënten) zijn, terwijl alle overige genoemde verzamelingen wel nominatief $z$ ijn;

- In het licht van het op blz. 104 e.v. gesignaleerde wantrouwen van de burgers tegen ,de overheid" is het opmerkelijk - en m.i. een omissie - dat geen der schrijvers aandacht heeft geschonken aan de vorig jaar genomen beslissing van de Minister van Binnenlandse Zaken, inhoudende dat persoonsgegevens slechts dan voldoende beschermd zouden zijn, indien $z \mathrm{ij}$ uitsluitend door overheidsorganen (d.i. door ambtenaren) worden beheerd. Op grond van deze beslissing is het tot dan bestaande beheer van een deel dier gegevens door een particuliere organisatie (met de nodige waarborgen) beëindigd. Naar mijn oordeel dient men zich toch op zijn minst af te vragen of dit een juiste, althans vertrouwenwekkende oplossing is, dan wel of een verschuiving naar van de (blijkens blz. 103 e.v. al dan niet terecht) gewantrouwde overheid onafhankelijke entiteiten de voorkeur zou verdienen;

$m a b$ blz. 120 
- Veel drukfouten bevat het boek zeker niet; men vraagt zich af warom de, alom bekende en niet-zinnige, drukfout ,aanwijzigingen" op blz. 65 is blijven staan.

\section{H. Igor Ansoff}

\section{ONDERNEMINGSSTRATEGIE; ANALYSE VAN HET ONDERNEMINGSBELEID GE- RICHT OP GROEI EN EXPANSIE}

Uitgave Samsom/NIVE, Alphen aan den Rijn/ 's-Gravenhage 1973 (vertaling), XVII + 240 blz., prijs $f 24,50$.

\section{door Drs. E. H. J. Bouma}

De laatste jaren is in Nederland (in navolging van het buitenland) een snel stijgende belang. stelling ontstaan voor het vraagstuk van de strategieformulering in de onderneming. Deze belangstelling blijkt, behalve uit het groeiend aantal ondernemingen dat zelf probeert een strategie te ontwikkelen, onder andere uit de oprichting van de Vereniging voor Strategische Beleidsvorming, het organiseren van een conferentie "Strategiekeuze en Ondernemingsplanning" door het NIVRA, een wassende stroom publicaties (zowel vertaald als oorspronkelijk) en tenslotte uit het bespreken van een van deze publicaties in dit blad.

Onmiddellijk rijst voor de belangstellende lezer de vraag: wat is ondernemingsstrategie en vanwaar die belangstelling?

Er bestaat een veelheid van definities van het begrip ondernemingsstrategie.

Eenvoudig gezegd gaat het bij al deze definities om de basiselementen; vaststellen van de ondernemingsdoelstellingen en selecteren van de wegen die tot realisatie van deze doelstellingen moeten leiden. Kernvraag hierbij is steeds: welke produkten of diensten moeten in de toekomst op welke markten afgezet worden.

Dat deze vraag de laatste jaren steeds meer in de belangstelling staat wordt veroorzaakt door een aantal factoren:

- het bedrijfsleven wordt dynamischer. Het produktie-pakket veroudert steeds sneller, de produktie moet efficienter gebeuren om kostenstijgingen het hoofd te bieden, de concurrentie wordt in toenemende mate agressief, zowel nationaal als internationaal.

de vrijheid van de onderneming bij het nemen van beslissingen wordt meer en meer inge-
Sterk aanbevolen aan allen die zich interesseren voor privacy-problemen in de era van computertoepassingen, dat is vandaag en morgen.

perkt door akties van overheid, vakbeweging, verenigingen tot bescherming van het milieu, enz.

Al deze factoren dwingen de onderneming veel meer dan vroeger regelmatig na te gaan in welke toestand zij zich bevindt, hoe haar positie is ten opzichte van haar concurrenten, welke kansen voor haar openliggen, welke bedreigingen op haar afkomen en welke alternatieven aanwezig zijn om die kansen te grijpen en die bedreigingen het hoofd te bieden. Kortom, deze factoren dwingen de onderneming tot het formuleren van een strategie.

Het was Prof. Ansoff die op dit terrein baanbrekend werk verrichtte met zijn in 1965 verschenen boek:

"Corporate Strategy; An Analytical Approach to Business Policy for "Growth and Expansion (1965)"

waarvan de vertaling hier besproken wordt.

Ansoffs boek is opgebouwd uit twee gedeelten. In de eerste hoofdstukken bouwt hij een model op voor het nemen van strategische beslissingen en formuleert hij een basisfilosofie. In de laatste hoofdstukken lost hij het strategieformuleringsprobleem op.

Kenmerkend voor Ansoff's strategie-model is de opbouw in fasen. Beslissingen worden in eerste instantie globaal geformuleerd en vervolgens, naarmate meer en betere informatie ter beschikking komt, steeds verder verfijnd. In elke fase van dit proces wordt vastgesteld of er een afwijking (kloof) bestaat tussen de huidige toestand (positie) van de onderneming en de door de leiding gewenste positie. (Deze gewenste positie blijkt uit de doelstellingen.) Bestaat er een kloof dan moet eerst geprobeerd worden of de onderneming deze binnen haar huidige produkt-marktpositie kan overbruggen (de zgn. interne taxatie). Blijkt dit niet te lukken dan moet de onderneming gaan zoeken naar interessante mogelijkheden buiten haar huidige produkt-marktpositie. Anders gezegd, zij moet gaan zoeken naar diversificatiemogelijkheden (de zgn. externe taxatie). Bij de behandeling van dit zoekproces gaat Ansoff in op vragen als: hoe moet de onderneming haar nieuwe activiteiten inpassen in haar organisatie en: moet zij 
groeien op eigen kracht of in samenwerking met derden?

Sinds het verschijnen van Ansoff's boek hebben veel ondernemingen getracht de door Ansoff ontwikkelde methoden zelf toe te passen. Hierbij zijn zij echter gestoten op een aantal belangrijke problemen die Ansoff in zijn boek onvoldoende of zelfs helemaal niet behandelt. Enkele van de belangrijkste hiervan zijn: - Ansoff besteedt onvoldoende aandacht aan de noodzaak bij de strategieformulering expliciet rekening te houden met allerlei veranderingen op maatschappelijk en technologisch terrein (inspraak eisende werknemers, organisaties van kritische consumenten). $\mathrm{Zijn}$ aandacht is bijna uitsluitend gericht op onderzoek van nieuwe produkt- en marktmogelijkheden.

- In tegenstelling tot de indruk die in het boek gewekt wordt is strategieformulering geen exclusief "onderonsje" voor het topmanagement. Een goede strategie kan alleen ontworpen worden als alle managementniveaus bij de formulering ervan een inbreng hebben.

- Aspecten als de strategische informatievoorziening, de financieringsstrategie, de relatie tussen strategie en structuur en de organisatie van de strategische planning komen niet of nauwelijks aan de orde.

Bij de publicatie van de nederlandse vertaling hadden de uitgevers de mogelijkheid het boek met of zonder aanvullend commentaar te publiceren. $\mathrm{Z}_{\mathrm{ij}}$ hebben gekozen voor het tweede alternatief, omdat naar hun mening een (kritische) commentaar Ansoff onrecht zou aandoen. Ik geloof dat dit een te betreuren beslissing is, die hen bovendien in conflict brengt met Ansoff's doelstelling: het schrijven van een boek over strategieformulering voor de man in de praktijk, voor de manager die de strategische beslissing moet nemen. Deze krijgt nu met de vertaling een boek in handen dat hij weliswaar beslist moet lezen, maar dat hem toch op een aantal punten ,,in de kou laat staan”. Ik kan mij nauwelijks voorstellen dat dit Ansoff's bedoeling zou kunnen zijn.

Nederlands-talige boeken die wel ingaan op de hiervoor genoemde lacunes zijn:

Strategie en Strategiebepaling

Dr. P. Croon

NIVE-publikatie nr. 549

(Eenvoudige uiteenzetting, bevat een zestal uitgewerkte praktijkvoorbeelden)

Planning voor de onderneming

R. L. Ackoff

Kluwer-Deventer

(Vertaling van: A concept of corporate planning) 